\title{
Networking for Foreign Direct Investment in Africa: How important are ICT Environment and Financial Sector Development?
}

\author{
Muazu Ibrahim ${ }^{1+}$, Ibrahim Osman Adam¹, Yakubu Awudu Sare ${ }^{1}$ \\ ${ }^{1}$ University for Development Studies, Ghana
}

\begin{abstract}
Studies on the drivers of Foreign Direct Investment (FDI) in Africa have not rigorously examined whether recent advances in the continent's Information, Communication and Technology (ICT) infrastructure and financial development have any role in attracting foreign capital. This study re-examines the determinants of FDI inflows, paying special attention to the ICT and financial sector environments. By relying on a panel dataset covering 46 countries in sub-Saharan Africa over the period 1980 2016, using the generalized method of moments (GMM) method, our study shows that well-developed ICT infrastructure robustly spurs FDI regardless of the measure of ICT. On the other hand, the impact of domestic financial development on FDI is conditioned on the proxy of finance. Specifically, while domestic (private) credit to GDP inhibits (promotes) foreign capital inflows, higher levels of ICT in the environment dampen the deleterious effect of finance on FDI. We document the threshold levels of ICT necessary to exert such dampening effects.
\end{abstract}

Keywords: FDI, ICT, Financial Development GMM, Africa

JEL Classifications: F21, C33, G2, O3

Received 19 November 2018, Revised 28 April 2019, Accepted 30 April 2019

\section{Introduction}

According to the World Investment Report (2017) of the United Nations Conference on Trade and Development, global Foreign Direct Investment (FDI) inflows declined by 2\% in 2016 to 1,746 billion US dollars, down from 1,774 billion US dollars in 2015, albeit with varying performance among continents and regions. For instance, while FDI in Europe dropped 5.8\%, 566 billion US dollars in 2015 to 533 billion US dollars in 2016, FDI inflows to Africa decreased by $3.5 \%$ from 61 billion US dollars in 2015 to 59 billion US dollars in 2016 and are expected to rise about $10 \%$ to 65 billion US dollars in 2017 as a result of modest increases in oil prices

\footnotetext{
+Comesponding Author: Muazu Ibrahim

Lecturer, School of Business and Law, Department of Banking and Finance, University for Development Studies, Post Office Box UPW 36, Wa, Upper West region, Ghana, Tel: +233208004800, email: imuazu@uds.edu.gh

Co-Author: Ibrahim Osman Adam

Senior Lecturer and Head of Department, School of Business and Law, Department of Accounting, University for Development Studies, Post Office Box UPW 36, Wa, Upper West region, Ghana

Co-Author: Yakubu Awudu Sare

Senior Lecturer and Dean, School of Business and Law, Department of Banking and Finance, University for Development Studies, Post Office Box UPW 36, Wa, Upper West region, Ghana
} 
and non-oil FDI. Although Africa accounts for 3.4\% of global FDI, foreign capital inflows in Africa remain unequally distributed across the continent, with only five countries (Angola, Egypt, Ethiopia, Ghana, and Nigeria) attracting $57 \%$ of the continent's total foreign capital inflows.

Basu and Srinivasan (2002) reviewed the experiences of some countries in sub-Saharan Africa (SSA) that have attracted fairly substantial amounts of foreign investment. The review shows that sustained efforts to promote political and macroeconomic stability as well as implementation of crucial structural reforms have significantly contributed to success in attracting a large amount of FDI. Dupasquier and Osakwe (2002) note that, factors such as political and macroeconomic instability, low growth, weak infrastructure, poor governance, inhospitable regulatory environments, and ill-conceived investment promotion strategies, are responsible for the poor FDI record of many SSA countries. In an attempt to attract foreign investment, several countries have been offering tax holidays, import duty exemptions, subsidies to foreign firms, and in some cases monopoly rights (Bouoiyour 2003). Despite efforts by African countries to attract FDI, FDI flows to the continent remain unimpressive. Recent evidence from the World Investment Report (2017: xiii) touts the digital economy as an important tool for attracting FDI and states that "the adoption of digital technologies has the potential to transform the international operations of MNEs and the impact of foreign affiliates on host countries."

In recent years, there has been a rapid diffusion of Information, Communication and Technology (ICT) throughout SSA. Growth in the ICT infrastructure in Africa has increased monotonically over the past decade. For instance, data from the International Telephone Union shows that, measured per 100 inhabitants, mobile cellular subscriptions have increased from 45.4 in 2010 to 65.5 in 2013, with a further increase to 77.8 in 2017. In addition, fixed broadband subscriptions increased from 0.2 in 2010 to 0.3 in 2012 with a further rise to 0.4 in 2017. Between 2013 and 2017, the number of individuals using the internet increased from 12.1 to 21.8.

Notwithstanding the impressive growth in the ICT environment in Africa, empirical studies on the impact of ICT on FDI have focused primarily on its implications for quality of life (Aker and Mbiti 2010, Asongu 2015) and overall economic growth (Dewan and Kraemer 2000, Pohjola 2002, Langmia 2005, Kpodar and Adranaivo 2011, Atsu et al. 2014, Albiman and Sulong 2015, Niebel 2018). Clearly, studies on the determinants of FDI in Africa still leave many avenues for further research in at least two important areas. First, focusing on the continent's evolving ICT environment, there is dearth of literature about how ICT development affects FDI trends in Africa. More importantly, we are unaware of how the different types of ICT indicators affect the continent's FDI inflows. Consequently, policymakers lack information about how the ICT environment shapes foreign capital and FDI in particular. This is important given Africa's low FDI inflows despite efforts to improve on the ICT infrastructure.

Second, there is a need to re-examine the mediation role of ICT on the link between domestic financial sector development and FDI. Empirical evidence on how financial development 
influences ICT-FDI nexus is lacking in this arena. Indeed, foreign investors, among others, are interested in sound financial systems similar to what prevails in their home countries.1) Thus, the development of the domestic financial sector coupled with an improved ICT environment is expected to spur growth. However, for the most part, evidence about the mediation effect of financial development on the ICT-FDI relationship in Africa is often sourced from public discourse with little theoretical and empirical grounding. Based on these observations, the current study makes four significant contributions to the literature. First, given the evolving ICT architecture and nascent financial systems in Africa, using recent data we update the literature by empirically examining how the ICT environment and financial development influence FDI. To the best of our knowledge, this is a pioneering study that has relied on several ICT indicators in addition to crucial ancillary factors influencing FDI. By separately using each indicator of ICT on its own merit, this study unearths their unique individual effects on FDI in Africa, which will be useful to policy makers. Second, this study investigates the mediation role of ICT in influencing the impact of financial systems on foreign capital inflows in SSA, given the low levels of the continent's ICT and financial systems. More specifically, by moving beyond the direct effect of ICT, this study uncovers indirect effects by examining the role ICT plays in the impact of financial development on FDI inflows in Africa. Third, given the potential importance of financial development on FDI, leveraging different indicators of financial development this study uses different proxies of ICT in examining their unique indirect effect on FDI via financial development. With this, we are able to highlight whether the form of financial development interacted with ICT to support or inhibit FDI inflows. Fourth, given the potential endogeneity problem eminent in FDI studies, we apply an estimation approach that deals with endogeneity and simultaneity bias, allowing us to provide results that are consistent and reliable.

Relying on a panel dataset covering 46 countries in Africa over the period 1980 2016, results from our system generalized method of moments (GMM) approach reveal a robust positive impact of ICT on FDI. However, the impact of financial sector development on FDI is conditioned on the indicator of finance. While availability of domestic credit-to-GDP as an indicator of financial development inhibits foreign capital inflows, a well-developed ICT environment dampens the deleterious effect of finance on FDI.

The rest of the study is organized as follows: the next section briefly reviews the literature while Section 3.0 outlines our methodology. Section 4.0 presents our empirical findings and discussions. We conclude the study with some key implications for policy in Section 5.0.

1) For a recent discussion on the determinants of financial development in Africa, see Ibrahim and Sare (2018) and Ibrahim and Alagidede (2017). 


\section{ICT and FDI Relationship: A Brief Review of the Literature}

The importance of FDI inflows has received much attention in the literature owing to its growth-enhancing effect. Latif et al. (2017) observe that ICT positively drives environmentally sustainable development in South Asia, albeit with variations in the long run impact of the ICT diffusion indicators. Recent evidence shows that the growth-enhancing effect may be conditioned on ICT usage. By using a panel estimation approach robust to heterogeneity and cross-sectional dependence, Latif et al. (2018) examine the dynamic relationship between ICT, FDI and economic growth while controlling for globalization in the so-called BRICS countries (Brazil, Russia, India, China, and South Africa). Evidence from their study suggests that ICT positively affects economic growth with variations in the level of impact stemming from the extent to which countries utilize ICT.

Indeed, efforts to study the drivers of FDI have often neglected the key role of countries' ICT environment in influencing FDI inflows (for instance, Sarbu and Carp 2015, Kida 2014). This is more pronounced in Africa, although a few studies are notable. For instance, Andrianaivo and Kpodar (2011) investigate the impact of ICT development on economic growth, considering a sample of 44 African countries during 1988 2007. Results from their system GMM approach suggest that the penetration rates of fixed and mobile telephones have had a significant and positive impact on growth. Relative to Sridhar and Sridhar (2004), the marginal impact of the fixed (land-line) penetration rate on economic growth appears stronger than that of the mobile penetration rate. However, Albiman and Sulong (2016) find nonlinear effects of ICT on growth. Their threshold analysis showed a penetration rate threshold of $4.5 \%$ for both mobile phone and internet usage, and 5\% for fixed telephone line before they can exert any positive effect on economic growth. Regarding transmission channels, the authors find that ICT enhances economic growth by improving human capital, institutional quality, and domestic investment in SSA. However, Albiman and Sulong (2016) find a negative interaction between ICT variables and financial development, suggesting a failure of ICT to reduce inefficiency in the region's financial sector. According to the authors, the dampening growth effect of ICT via the financial sector is attributable to structural weaknesses within the financial sector in SSA.

Beyond the ICT-economic growth nexus, few studies have examined the impact of ICT on FDI. On the empirical front, Asiedu (2002) analyzes the drivers of FDI in developing countries (SSA and non-SSA) and why SSA has lagged behind in attracting FDI. The author finds that while infrastructure, measured by the number of telephones per 1,000 population, and higher returns to capital are essential in promoting FDI to non-SSA, in the case of SSA, these variables are insignificantly related to FDI. Further evidence reveals that, regardless of the region, trade openness spurs FDI, albeit with reduced effect in SSA. Thus, trade liberalization tends to generate more FDI inflows to non-SSA relative to SSA countries. 
Choi (2003) argues that international direct investors may well choose the country with greater internet availability measured by the number of internet hosts or users in a host country, using a gravity FDI model with bilateral FDI data from 14 source countries and 53 host countries. This result is robust to an alternative internet variable and alternative estimation approaches. By using the residuals of the number of telephone lines per 100 as a proxy for ICT, Reynolds et al. (2004) finds that countries with one additional phone per 100 people than predicted by their income level will have 0.03 cents more FDI per dollar of GDP. Jordaan (2004) argues that foreign capital would flow to countries with larger markets and higher purchasing power, where firms have the potential to earn a higher return on their capital. Other studies (Ang 2008, Pärletun 2008) have found a positive effect of market size on FDI. The logic is that a higher GDP per capita presents better prospects for FDI in the host country. Thus, an expansion of market size attracts foreign investors.

Lydon and Williams (2005) find that average FDI inflows into developing countries are higher in countries with better telecommunications networks. Not only is the impact of fixed telephone penetration on FDI flows significant, it is economically larger than mobile penetration rates. However, relying on panel data involving 74 industrialized and developing countries over the period 1980 2000, Alsan et al.'s (2005) study does not reveal any significant effect of fixed telephone lines on FDI. Thus, this finding is inconsistent with Aseidu (2002).

Demirhan and Masca (2007) also find that the growth rate of telephone main lines per capita, and degree of trade openness have positive and significant impact on FDI while inflation and taxes dampen FDI inflows. However, labor costs, proxied by wages per worker in the manufacturing sector, have no impact on foreign capital inflows in developing countries. By juxtaposing the drivers of FDI, Walsh and Yu (2010) observe that domestic macroeconomic conditions such as a stronger exchange rate and a lower inflation rate matter more for attracting tertiary FDI into advanced countries. However, in emerging economies, these effects appear weaker. Relying on a panel of seven 5-year non-overlapping windows for the period 1980 2007, Anyanwu (2011) examines the determinants of FDI in Africa. Results from the study show that while market size-proxied by urban population share-and trade openness positively and significantly spur FDI inflows, higher domestic financial sector development inhibits foreign capital inflows in Africa. However, using a data from 96 developing countries including Africa, Munemo (2017) finds there is a threshold level of financial development above which FDI "crowds in" new businesses.

Cardona et al. (2013) provide an extensive survey of the vast empirical literature on ICT and productivity and argue that ICT spurs productivity with an increasing effect over time. While they contend that variations in the empirical findings of existing studies are largely driven by methodological differences, having a significant ICT effect does not necessarily spur productivity merely by incremental investments in ICT. To the authors, ICT development has 
to be entrenched in complementary organizational investments, skills and industry structures. Using annual time series data for South Africa for the period 1991 2013 and invoking the autoregressive distributed lag approach to cointegration, Salahuddin and Gow (2016) find a positive and significant long run relationship between internet usage and economic growth with a unidirectional causality running from the former to the latter.

Given the above discussion, this current study aims at investigating whether the different ICT indicators explain FDI inflows in Africa, in addition to examining how the ICT environment mediates the relationship between financial development and FDI. By thoroughly examining the varying effect of ICT and how it influences the link between different proxies of financial development and FDI, this study differs from the existing literature. We discuss our methodology in the next section.

\section{Methodology}

\section{A. Data and preliminary findings}

We create an annual panel dataset of 46 countries in Africa over the period 1980 2016, with the choice of countries and time span selected based on data availability over a lengthy time span.2) Data on all of these variables were sourced from the World Development Indicators (WDI) of the World Bank. According to the WDI, FDI is defined as a net inflow of investment to acquire a lasting management interest of at least $10 \%$ of voting rights in firms in host economies. It includes equity capital and other long and short-term capital. Our FDI variable is measured as a percentage of GDP. We use five indicators to proxy the ICT environment. The first is ICT goods imports as a percentage of total goods imports. This consists of equipment imports to support ICT development, including computers and peripheral devices, communication equipment, consumer electronic equipment, electronic components, and other information and technology goods. A second measure is the percent of the population using the internet, which includes individuals who have used the internet (from any location) during the last three months, from any platform, including a computer, mobile phone or personal digital assistant, among others. The third measure is cellular telephone subscriptions (per 100 people), defined as subscriptions to a public mobile telephone service that provide access to the PSTN using cellular technology. The indicator includes the number of postpaid subscriptions, and the number of

2) The countries are Algeria, Angola, Benin, Botswana, Burundi, Burkina Faso, Cape Verde, Cameroon, Central African Republic, Chad, Congo, Dem. Rep., Congo, Rep., Cote d'Ivoire, Ethiopia, Egypt, Arab Rep., Equatorial Guinea, Gabon, Ghana, The Gambia, Guinea-Bissau, Guinea, Kenya, Liberia, Libya, Lesotho, Mali, Malawi, Mauritania, Mauritius, Morocco, Niger, Nigeria, Namibia, Mozambique, Rwanda, Senegal, Sierra Leone, South Africa, Sudan, Swaziland, Tanzania, Togo, Tunisia, Uganda, Zambia, and Zimbabwe. 
active prepaid accounts that have been used in the last three months. The fourth measure is fixed telephone subscriptions (per 100 people), referring to the sum of active number of analog fixed telephone lines, voice-over-IP subscriptions, fixed wireless local loop subscriptions, ISDN voice-channel equivalents, and fixed public payphones. Finally, secure internet servers (per 1 million people) as an ICT measure refers to servers using encryption technology in internet transactions.

We also use two indicators of financial sector development: the ratios of private and domestic credits to GDP. Private credit refers to financial resources provided to the private sector by financial corporations, such as through loans, purchases of non-equity securities and trade credits. Domestic credit provided by the financial sector includes all credit to various sectors on a gross basis, with the exception of credit to the Central government. Therefore, private and domestic credits to GDP are more directly linked to investment (Ibrahim and Alagidede 2018a,b). We proxy a country's level of income with real GDP per capita measured in constant 2010 U.S. dollars, while population aged 15-64 (\% of total) is used as the measure of active labor. Trade openness is proxied by the ratio of the sum of imports and exports to GDP. Human capital accumulation is measured by primary school enrolment as a percentage of the school-aged population while inflation is the annual percentage change in the consumer price index and is used to indicate a country's economic (in)stability. These control variables are chosen following standards in the literature (Aseidu 2002, Hausmann and Fernandez-Arias 2000, Jaspersen et al. 2000). We present the descriptive statistics of our variables in Table 1 below.

Table 1. Descriptive statistics

\begin{tabular}{lccc}
\hline Variable & Mean & Standard deviation & Coefficient of variation \\
\hline ICT goods imports & 4.282 & 2.127 & 0.497 \\
Individuals using internet & 6.029 & 10.435 & 1.731 \\
Mobile cellular & 20.383 & 36.130 & 1.773 \\
Fixed telephone & 2.323 & 4.262 & 1.835 \\
Secure internet & 6.331 & 20.126 & 3.179 \\
FDI & 3.394 & 9.054 & 2.668 \\
Private credit & 20.415 & 21.857 & 1.071 \\
Domestic credit & 32.967 & 62.576 & 1.898 \\
Primary school enrolment & 88.354 & 27.883 & 0.316 \\
GDP per capita & $1,924.433$ & $2,593.697$ & 1.348 \\
Population & 53.648 & 4.624 & 0.086 \\
Trade openness & 73.248 & 45.417 & 0.620 \\
Inflation & 59.619 & 896.304 & 15.034 \\
\hline
\end{tabular}

From Table 1, the mean value of ICT goods imports is $4.282 \%$ of total imports while the percent of individuals using the internet averages $6.029 \%$. The average level of mobile telephone 
subscriptions is 20 per 100 people with a standard deviation of 36.13. The mean net FDI is $3.394 \%$, and the low FDI inflow is consistent with Africa's share of global FDI as reported in the World Investment Report (2017). Turning to financial development, the mean value of domestic credit is higher than that of private credit, while the low average GDP per capita

Figure 1. ICT and FDI nexus
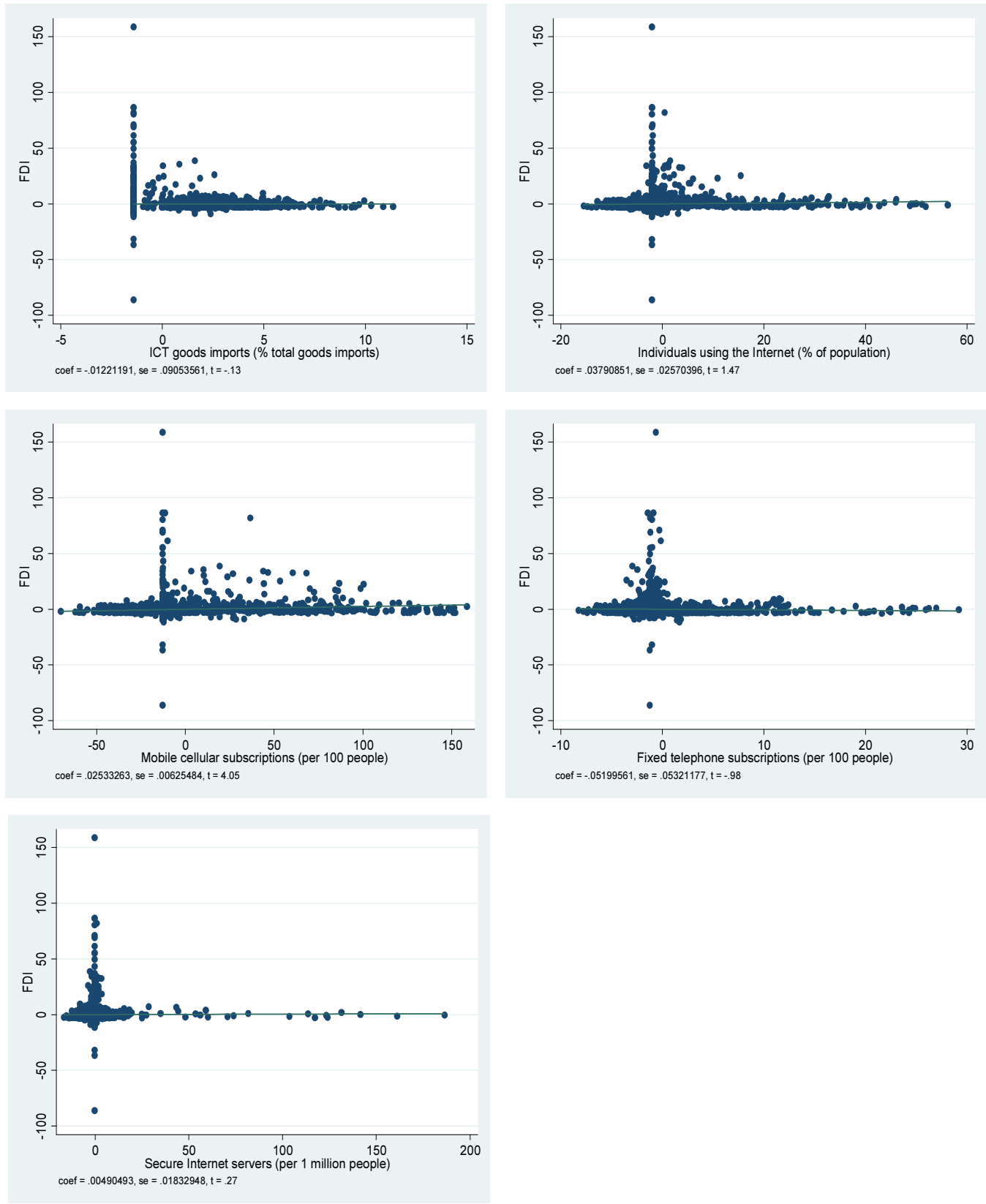
reaffirms Africa's low-income status coupled with high inflation. We compute coefficient of variation as the ratio standard deviation to mean in order to examine the inter-level volatility of the variables. We find that, among the ICT indicators, secured internet is the most volatile given the larger value of the coefficient of variation while ICT goods import is the least volatile. Similarly, regarding the financial development, domestic credit is the most volatile relative to private credit while inflation has the highest coefficient of variation. With a cursory look at the descriptive statistics above, we examine the ICT and FDI link using simple regression plots, shown in Figure 1. Apart from ICT goods imports and fixed telephone subscription, the data shows some evidence of a positive link between ICT and FDI. However, it is also clear there is some variability in the magnitude of effect and level of significance.

\section{B. Empirical strategy}

To empirically examine the drivers of FDI, we set a baseline model where foreign capital inflow is conditioned on its lag, levels of ICT development, financial sector development, and other factors. We specify Equation (1) below:

$$
F D I_{i t}=\varpi_{o} F D I_{i t-1}+\varpi_{1} I C T_{i t}+\varpi_{2} F I N_{i t}+\varpi_{3} C O N_{i t}+\mu_{i t}
$$

where $i$ and $t$ represent country and time indices respectively; $F D I_{i t-1}$ is the one-period lagged FDI used to measure the initial conditions of FDI in Africa; $I C T_{i t}$ and $F I N_{i t}$ are vectors of ICT and financial development indicators respectively; $C O N_{i t}$ denotes a vector of other controls such as human capital, real GDP per capita, population, trade openness and inflation; $\mu_{i t}$ is the error term.

Thus, from Equation (1), ICT supports FDI when its coefficient, $\varpi_{1}>0$ and significant at conventional levels; otherwise, the digital economy in Africa does not appear to support foreign inflows. Beyond the unconditional impact of ICT, we determine whether there is a conditional effect of ICT via a country's financial sector development. To do so, we include in the equation above, a multiplicative interactive term of ICT and financial development indicators as shown below:

$$
\begin{aligned}
& F D I_{i t}=\varpi_{o} F D I_{i t-1}+\varpi I C T_{i t}+\varpi_{2} F I N_{i t}+\varpi_{3} C O N_{i t}+\psi\left(I C T_{i t} \times F I N_{i t}\right)+\varepsilon_{i t} \\
& \varepsilon_{i t}=\beta_{i}+\nu_{t}+\mu_{i t}
\end{aligned}
$$

where $\beta_{i}$ is unobserved country-specific fixed effect; $\nu_{t}$ is the time effect while $\varepsilon_{i t}$ is the idiosyncratic error term. From Equation (2), the interactive effect is measured by $\psi$ and is 
expected to shed light on the impact of simultaneous development of the ICT and financial sector.

Indeed, from both equations above, including the lagged dependent variable suggests a potential correlation between the factors driving FDI and the error term, since lagged FDI depends on $\varepsilon_{i t-1}$, which is a function of the country-specific effect $\left(\beta_{i}\right)$. Thus, our specified equations suffer from endogeneity due to this correlation. Because of the endogeneity following from the inclusion of the lagged dependent in Equations 1 and 2, using pooled ordinary least squares or other panel estimation approaches (notably the fixed and random effects, mean group and pooled mean group) that do not deal with the endogeneity produces results that are not reliable. To control for this endogeneity problem, we use the GMM method that corrects this problem and in so doing, produces efficient and reliable results.

We therefore estimate the equations relying on the GMM method proposed by Arellano and Bond (1991) which eliminates $\beta_{i}$ or any related time invariant, country-specific variable present in the data. According to Baltagi et al. (2009), taking the first difference in the use of GMM has an added advantage. First, this procedure removes any endogeneity stemming from the correlation of $\beta_{i}$ with the right-hand side regressors. Second, by differencing, the GMM estimation approach helps to ensure that all the regressors are stationary. In this study, we rely on the system GMM which combines a regression in its first differences and in its levels (Arellano and Bover 1995, Blundell and Bond 1998).

Roodman (2009) cautions on the use of system GMM estimators, especially when $T$ is small relative to the number of internally determined instruments. To the extent that too many instruments potentially over-fit our instrumented variables, for the lagged FDI we use as instruments the first difference lagged one period for the Equations levels. However, for the Equations using first differences, we rely on the first lagged value. With regard to the other regressors that are assumed to be endogenous, we use the second lagged value as instruments. Based on this, we adopt the two-step system GMM. The validity of our instruments is checked using the Sargan test of over-identifying restrictions which examines whether our set of instruments, as a group, are exogenous. In addition, we also test for the absence of second-order serial correlation of the residuals.

\section{Empirical Findings}

This section presents our empirical findings regarding the determinants of FDI. Our emphasis is on how the ICT diffusion indicators individually affect FDI. In this endeavor, combining all indicators together in a single equation may yield reliable results. A more important problem that one might encounter if all of the indicators are included in the same model is multicollinearity. 
Because the indicators of ICT are related and linked to each other, the probability of their being correlated with each other is very high. Therefore, putting the different ICT indicators together in a single model would result in multicollinearity, which might produce unreliable results. We circumvent this by including a single ICT measure. Specifically, in separate regressions, we determined how each ICT indicator uniquely affects FDI in addition to other regressors including financial sector development. For the financial development indicator, we first used private credit to proxy domestic financial development in examining how it influences FDI. We also conducted a sensitivity analysis by altering the proxy of financial sector development. In Table 2, we present findings on the drivers of foreign capital inflows.

Table 2 reports on the drivers of FDI, in addition to the impact of ICT and financial sector development. The coefficients of lagged FDI are positive and significant at $1 \%$, denoting a conditional divergence. This suggests that countries in our sample diverge to their own steady state FDI; this holds for all of our model specifications. Economically, this evidence may well suggest that current levels of FDI depend on the continent's past inflows of foreign capital. For the ICT indicators-FDI nexus, we find positive and statistically significant coefficients for all of the indicators. Beginning with the impact of imports of ICT goods, we find that a unit-percentage increase in ICT imports increases FDI inflows by $0.0336 \%$. Indeed, imports of computers, communication and electronic devices, which is expected to enhance the ICT infrastructure, improves access to information regarding effective investment portfolios. As a result, inflows of FDI to host economies increase. Similarly, individuals using the internet improve FDI inflows, as does secured internet use. Internet usage from any location as well as servers relying on encryption technology for internet transactions enhances FDI by 0.0409 and $0.0103 \%$, respectively. Anecdotally, increasing internet usage reduces transaction costs and subsequently production costs within an increasingly competitive environment, thereby enhancing FDI inflows (Gani and Sharma 2003, Choi 2003). Thus, access to and use of the internet provides quicker information to foreign investors regarding investment opportunities and as such plays a critical role in attracting FDI. Ko (2007) finds an insignificant effect of internet usage on FDI, suggesting that the increasing population of users puts intense pressure on available internet connectivity, thereby creating congestion which ultimately inhibits FDI. Our finding, however, does not support this view. Indeed, investment in improving internet speed and imports of peripheral equipment support reliable internet connectivity on the back of more users.

While ICT infrastructure enhances net inflows of FDI, we notice that the impact of fixed telephone subscriptions (per 100 people) is higher, suggesting that fixed networks are exceedingly important in influencing FDI inflows, consistent with Lydon and Williams (2005). We conjecture that fixed network and telephone line penetration in Africa has some bearing on the extent and quality of other proxies of infrastructure, notably roads, which are developed over a period of time. Indeed, in addition to fixed telephone subscriptions, the ancillary 
Table 2. ICT, Finance and FDI nexus

\begin{tabular}{|c|c|c|c|c|c|}
\hline MODEL \# & 1 & 2 & 3 & 4 & 5 \\
\hline Lagged FDI & $\begin{array}{c}0.17630^{* * *} \\
{[0.000]}\end{array}$ & $\begin{array}{c}0.17430^{* * *} \\
{[0.000]}\end{array}$ & $\begin{array}{c}0.17520^{* * *} \\
{[0.000]}\end{array}$ & $\begin{array}{c}0.17280^{* * *} \\
{[0.000]}\end{array}$ & $\begin{array}{c}0.17660^{* * *} \\
{[0.000]}\end{array}$ \\
\hline ICT imports & $\begin{array}{c}0.03360^{* * *} \\
{[0.000]}\end{array}$ & & & & \\
\hline Internet usage & & $\begin{array}{c}0.04090^{* * *} \\
{[0.000]}\end{array}$ & & & \\
\hline Mobile cellular & & & $\begin{array}{c}0.01140 * * * \\
{[0.000]}\end{array}$ & & \\
\hline Fixed telephone & & & & $\begin{array}{c}0.61540^{* * *} \\
{[0.000]}\end{array}$ & \\
\hline Secured internet & & & & & $\begin{array}{c}0.01030^{* *} \\
{[0.028]}\end{array}$ \\
\hline Private credit & $\begin{array}{c}0.04140^{* * *} \\
{[0.000]}\end{array}$ & $\begin{array}{c}0.02330^{* * *} \\
{[0.001]}\end{array}$ & $\begin{array}{c}0.01990^{* * *} \\
{[0.000]}\end{array}$ & $\begin{array}{c}0.04290 * * * \\
{[0.000]}\end{array}$ & $\begin{array}{c}0.03290^{* * *} \\
{[0.000]}\end{array}$ \\
\hline Human capital & $\begin{array}{c}-0.00290 * * * \\
{[0.000]}\end{array}$ & $\begin{array}{c}-0.00060^{*} \\
{[0.060]}\end{array}$ & $\begin{array}{c}-0.00070^{*} \\
{[0.073]}\end{array}$ & $\begin{array}{c}-0.00480^{* * *} \\
{[0.000]}\end{array}$ & $\begin{array}{c}-0.00160 * * * \\
{[0.000]}\end{array}$ \\
\hline Real GDP per capita & $\begin{array}{c}-0.00090^{* * *} \\
{[0.000]}\end{array}$ & $\begin{array}{c}-0.00090^{* * *} \\
{[0.000]}\end{array}$ & $\begin{array}{c}-0.00080^{* * *} \\
{[0.000]}\end{array}$ & $\begin{array}{c}-0.00100 * * * \\
{[0.000]}\end{array}$ & $\begin{array}{c}-0.00090 * * * \\
{[0.000]}\end{array}$ \\
\hline Population & $\begin{array}{c}0.26320 * * * \\
{[0.006]}\end{array}$ & $\begin{array}{c}0.15050 \\
{[0.328]}\end{array}$ & $\begin{array}{c}0.14280 \\
{[0.482]}\end{array}$ & $\begin{array}{c}0.14690 \\
{[0.147]}\end{array}$ & $\begin{array}{c}0.27860^{* * *} \\
{[0.001]}\end{array}$ \\
\hline Trade openness & $\begin{array}{c}0.07710^{* * * *} \\
{[0.000]}\end{array}$ & $\begin{array}{c}0.07750 * * * \\
{[0.000]}\end{array}$ & $\begin{array}{c}0.07710^{* * *} \\
{[0.000]}\end{array}$ & $\begin{array}{c}0.07640 * * * \\
{[0.000]}\end{array}$ & $\begin{array}{c}0.07760^{* * *} \\
{[0.000]}\end{array}$ \\
\hline Inflation & $\begin{array}{c}-0.00008 \\
{[0.219]}\end{array}$ & $\begin{array}{c}-0.00004 \\
{[0.562]}\end{array}$ & $\begin{array}{c}-0.00008 \\
{[0.096]}\end{array}$ & $\begin{array}{c}-0.00008 \\
{[0.142]}\end{array}$ & $\begin{array}{c}-0.00008 \\
{[0.200]}\end{array}$ \\
\hline Constant & $\begin{array}{c}-16.02670 \\
{[0.002]}\end{array}$ & $\begin{array}{c}-9.70210 \\
{[0.229]}\end{array}$ & $\begin{array}{c}-9.40900 \\
{[0.386]}\end{array}$ & $\begin{array}{c}-10.68600 \\
{[0.047]}\end{array}$ & $\begin{array}{c}-16.69960 \\
{[0.000]}\end{array}$ \\
\hline \multicolumn{6}{|l|}{ Diagnostics } \\
\hline Time effects & YES & YES & YES & YES & YES \\
\hline Wald $\chi^{2}$ & $56,332.95$ & $40,657.59$ & $395,285.92$ & $124,387.71$ & $112,131.87$ \\
\hline Prob $>\chi^{2}$ & 0.0000 & 0.0000 & 0.0000 & 0.0000 & 0.0000 \\
\hline AR (2) $[p$-value $]$ & $-1.634[0.194]$ & $-1.734[0.163]$ & $-1.534[0.177]$ & $-1.231[0.153]$ & $-1.540[0.134]$ \\
\hline Sargan test $[p-$ value $]$ & $15.342[0.281]$ & $13.044[0.212]$ & $16.018[0.311]$ & $19.421[0.298]$ & $20.430[0.222]$ \\
\hline Number of groups & 46 & 46 & 46 & 46 & 46 \\
\hline
\end{tabular}

(Notes) $* * *$ and $* * *$ denote significance at 10,5 and $1 \%$ respectively. Windmeijer (2005) robust standard errors are used.

infrastructure that often comes with fixed network penetration aids in attracting higher FDI.

Given the size of the coefficient for mobile cellular our results shows that although mobile subscriptions on the continent have grown significantly, this improvement is yet to have large impact on FDI. To the extent that mobile telephony and penetration is recent in Africa, coupled with mobile network connectivity problems, potentially explains this marginal impact. Indeed, the use of ICT indicators facilitates communication between home and host countries. Our 
overall evidence supports a complementary role for ICT and, as indicated by Addison and Heshmati (2003), suggests ICT infrastructure and skills are critical in integrating local producers into international technological and communications networks, and in attracting FDI.

With regard to the impact of finance on FDI, we find a robustly positive and statistically significant effect of private credit on FDI inflows. More specifically, a $1 \%$ increase in private credit spurs FDI inflows of between 0.0199 to $0.0429 \%$. Indeed, this large impact is recorded once we control for fixed telephone penetration (Model 4). Our findings largely reveal that a well-developed domestic financial sector enhances FDI inflows. The implication is that a sufficiently developed financial system directly enhances the creation of new firms and hence encourages FDI. A relatively well-developed financial market helps to attract foreign investors, as such a market is perceived to be a sign of improved financial intermediation and a market-friendly environment. To the extent that well-developed financial institutions reduce transactions costs and permit efficient allocation of capital from low productivity to investment projects (McKinnon 1973, Shaw 1973, Hull and Tesar 2003), this is expected to significantly drive inflow of FDI to host economies.

Evidence abounds that a well-educated population is a conduit for FDI inflows (Eicher and Kalaitzidakis 1997). Early theoretical writers (Easterlin 1981, Lucas 1990) argue that low skills and poorly trained people erode the rate of return of FDI, thereby inhibiting capital inflows. Thus, economies with improved human capital attract more FDI. However, this study does not find evidence of an FDI-enhancing effect of human capital. What we found is rather a crowding out of foreign capital, based on the negative coefficient of human capital proxied by gross primary school enrolment. Although the impact of human capital on FDI is not economically large, it is robust to model specification. In fact, to the extent our sampled countries are comparatively low-income countries, they may be more competitive in the FDI market due to the ability to accept lower wages for unskilled workers. While this finding may be surprising, we proffer two possible explanations. First, an increase in human capital may stimulate local entrepreneurial activity, thus increasing domestic investment relative to foreign investment as a proportion of GDP. Individuals may become more nationalistic as a result of improved human capital and may increase their domestic investment. Second, our measure of human capital is largely a quantitative indicator (Ibrahim 2018) which may not be relevant for FDI. Perhaps, it is the quality of human capital that matters for foreign capital inflows. Our finding on the human capital-FDI nexus is consistent with Mina (2007).

Similarly, income proxied by real GDP per capita has an inverse relationship with FDI inflows. The coefficients are robustly negative and significant at $1 \%$. The implication is that poor (rich) countries receive more (less) FDI relative to countries with high GDPs. This is contrary to the evidence that higher GDP per capita is associated with higher purchasing power, which encourages foreign entry, which would make FDI positively related to a country's per 
capita income. However, the negative coefficients of per capita income in our study do not support this view and suggest higher foreign capital flows into economies with relatively low per capita income. It could be that low-income countries deliberately implement measures to attract FDI as a method of boosting economic status. This finding is inconsistent with Asiedu (2002) who found a positive relationship between FDI and per capita GDP in Africa. Turning to population, the study finds that the impact of population on FDI is positively and largely insignificant with the exception of regressions containing ICT imports and secure internet, where the population-FDI nexus is significant at $1 \%$ with economically huge coefficients. Here the implication is that a larger population is associated with higher FDI. However, the difference in the level of significance across models suggests this effect is not a robust determinant.

Regarding trade openness, we find a robustly positive effect of trade openness on FDI. In the model controlling for ICT imports (Model 1), our evidence suggests that a unit-percentage increase in trade openness significantly improves net FDI inflows by $0.0771 \%$. Similar evidence holds for the other model specifications, revealing that the more opened an economy, the higher the FDI inflows. Indeed, openness is required for both import and export activities, and because many FDI schemes may involve the purchase (and sale) of intermediate inputs across borders, higher foreign capital is registered in economies with greater trade openness. Thus, multinational firms engaged in export-oriented activities may desire to invest in relatively more open economies since greater market imperfections associated with trade restrictions increase transaction and other upfront costs associated with cross-border trading.

Andinuur (2013) views low inflation as a sign of internal economic stability in the host country and it is expected to increase FDI. Thus, foreign investors may invest in foreign countries with a more stable economy for improved profitability and cash flow. Therefore, levels of inflation and FDI are negatively related. However, while the coefficient of inflation is negative, none of the effects are statistically significant. The implication is that the level of economic (in)stability in Africa does influence FDI given the negative coefficients of inflation, albeit insignificantly.

Given the impact of ICT and financial development on FDI, we investigate whether an improved ICT environment magnifies the relationship between finance and FDI. Specifically, we examine the indirect impact of ICT through the financial sector. On this score, we include an interactive term of finance and ICT into the FDI Equation. Here, our focal independent variables are ICT, private credit and the multiplicative interactive term which tests the significance of the domestic financial market as a conduit for facilitating the positive impact of ICT. Indeed, our inclusion of both ICT and private credit as individual regressors guarantees that the multiplicative interactive term does not serve as a proxy for ICT and finance. There exists a threshold effect of finance above which ICT begins to positively impact FDI if $\varpi_{1}<0$ [direct effect of ICT] and $\psi>0$ [coefficient of the interactive term]. Following Munemo (2017), we 
Table 3. ICT, Finance, FDI, and mediation effects

\begin{tabular}{|c|c|c|c|c|c|}
\hline MODEL \# & 1 & 2 & 3 & 4 & 5 \\
\hline Lagged FDI & $\begin{array}{c}0.17590^{* * *} \\
{[0.000]}\end{array}$ & $\begin{array}{c}0.17310^{* * *} \\
{[0.000]}\end{array}$ & $\begin{array}{c}0.17500^{* * *} \\
{[0.000]}\end{array}$ & $\begin{array}{c}0.16970^{* * *} \\
{[0.000]}\end{array}$ & $\begin{array}{c}0.17560^{* * *} \\
{[0.000]}\end{array}$ \\
\hline ICT imports & $\begin{array}{c}-0.01320 \\
{[0.652]}\end{array}$ & & & & \\
\hline Internet usage & & $\begin{array}{c}0.04570^{* * *} \\
{[0.002]}\end{array}$ & & & \\
\hline Mobile cellular & & & $\begin{array}{l}0.00570 \\
{[0.131]}\end{array}$ & & \\
\hline Fixed telephone & & & & $\begin{array}{c}0.62030 * * * \\
{[0.000]}\end{array}$ & \\
\hline Secured internet & & & & & $\begin{array}{c}0.05460 \\
{[0.208]}\end{array}$ \\
\hline Private credit & $\begin{array}{c}0.03140 * * * \\
{[0.000]}\end{array}$ & $\begin{array}{c}0.02640 * * * \\
{[0.000]}\end{array}$ & $\begin{array}{c}0.01940 * * * \\
{[0.000]}\end{array}$ & $\begin{array}{c}0.03350^{* * *} \\
{[0.000]}\end{array}$ & $\begin{array}{c}0.02940^{* * *} \\
{[0.000]}\end{array}$ \\
\hline Human capital & $\begin{array}{c}-0.00260 * * * \\
{[0.000]}\end{array}$ & $\begin{array}{c}-0.00050 \\
{[0.203]}\end{array}$ & $\begin{array}{c}-0.00020 \\
{[0.646]}\end{array}$ & $\begin{array}{c}-0.00390 * * * \\
{[0.000]}\end{array}$ & $\begin{array}{c}-0.00120^{* *} \\
{[0.024]}\end{array}$ \\
\hline Real GDP per capita & $\begin{array}{c}-0.00090 * * * \\
{[0.000]}\end{array}$ & $\begin{array}{c}-0.00080^{* * *} \\
{[0.000]}\end{array}$ & $\begin{array}{c}-0.00090 * * * \\
{[0.000]}\end{array}$ & $\begin{array}{c}-0.00110 * * * \\
{[0.000]}\end{array}$ & $\begin{array}{c}-0.00080 * * * \\
{[0.000]}\end{array}$ \\
\hline Population & $\begin{array}{c}0.37160^{* * *} \\
{[0.000]}\end{array}$ & $\begin{array}{c}0.14810 \\
{[0.421]}\end{array}$ & $\begin{array}{c}0.49230^{* * *} \\
{[0.008]}\end{array}$ & $\begin{array}{c}0.24870^{* *} \\
{[0.035]}\end{array}$ & $\begin{array}{c}0.19740 \\
{[0.119]}\end{array}$ \\
\hline Trade openness & $\begin{array}{c}0.07740^{* * *} \\
{[0.000]}\end{array}$ & $\begin{array}{c}0.07760^{* * *} \\
{[0.000]}\end{array}$ & $\begin{array}{c}0.07690^{* * *} \\
{[0.000]}\end{array}$ & $\begin{array}{c}0.07640^{* * *} \\
{[0.000]}\end{array}$ & $\begin{array}{c}0.07720^{* * *} \\
{[0.000]}\end{array}$ \\
\hline Inflation & $\begin{array}{c}-0.00010 \\
{[0.046]}\end{array}$ & $\begin{array}{l}-0.00006 \\
{[-0.395]}\end{array}$ & $\begin{array}{c}-0.00004 \\
{[0.597]}\end{array}$ & $\begin{array}{c}-0.00005 \\
{[0.158]}\end{array}$ & $\begin{array}{c}-0.00006 \\
{[0.366]}\end{array}$ \\
\hline \multicolumn{6}{|l|}{ Interactions: } \\
\hline Private credit $\times$ ICT imports & $\begin{array}{l}0.00110 \\
{[0.385]}\end{array}$ & & & & \\
\hline Private credit $\times$ Internet usage & & $\begin{array}{c}-0.00030 \\
{[0.204]}\end{array}$ & & & \\
\hline Private credit $\times$ Mobile cellular & & & $\begin{array}{l}0.00003 \\
{[0.486]}\end{array}$ & & \\
\hline Private credit $\times$ Fixed telephone & & & & $\begin{array}{c}-0.00040 \\
{[0.881]}\end{array}$ & \\
\hline Private credit $\times$ Secured internet & & & & & $\begin{array}{c}-0.00040 \\
{[0.271]}\end{array}$ \\
\hline Constant & $\begin{array}{c}-21.62330 \\
{[0.000]} \\
\end{array}$ & $\begin{array}{c}-9.83980 \\
{[0.318]} \\
\end{array}$ & $\begin{array}{c}-27.90700 \\
{[0.005]} \\
\end{array}$ & $\begin{array}{c}-15.99910 \\
{[0.012]} \\
\end{array}$ & $\begin{array}{c}-12.44410 \\
{[0.065]} \\
\end{array}$ \\
\hline \multicolumn{6}{|l|}{ Diagnostics } \\
\hline Time effects & YES & YES & YES & YES & YES \\
\hline Wald $\chi^{2}$ & $84,799.37$ & $142,516.57$ & $153,218.49$ & $66,445.78$ & $108,055.23$ \\
\hline Prob $>\chi^{2}$ & 0.0000 & 0.0000 & 0.0000 & 0.0000 & 0.0000 \\
\hline AR (2) $[p$-value $]$ & $-1.412[0.201]$ & $-1.129[0.211]$ & $-1.190[0.205]$ & $-1.521[0.225]$ & $-1.600[0.241]$ \\
\hline Sargan test $\left[p^{-}\right.$-value $]$ & $21.29[0.227]$ & $24.792[0.207]$ & $19.021[0.266]$ & $15.103[0.259]$ & $17.612[0.213]$ \\
\hline Number of groups & 46 & 46 & 46 & 46 & 46 \\
\hline
\end{tabular}

(Notes) $* *$ and $* * *$ denote significance at 5 and $1 \%$ respectively. Windmeijer (2005) robust standard errors are used. 
determine an inflection point of finance as $I C T \geq-\frac{\varpi_{1}}{\psi}$. However, if both $\varpi_{1}$ and $\psi$ are either negative or positive, then the impact of ICT on FDI is monotonically positive or negative. Table 3 below presents results of the interaction effects in addition to the other variables.

In these estimations, the impact of ICT on FDI is not robust. For instance, the effect of ICT imports is negative but not significant. While the other indicators of ICT are positively related to FDI, only the impact of internet usage and fixed telephone subscriptions are significant. Not only are individual internet usage and fixed telephone significant, their coefficients are also economically large relative to earlier findings shown in Table 2. The impact of finance on FDI maintains both its direction and level of significance where a well-developed domestic financial sector spurs net FDI inflows. With respect to the moderation effects, we observe that apart from the interactive terms of private credit and ICT imports, and private credit and mobile cellular subscriptions, the coefficients of the other interactive terms are positive. What is paramount, however, is that all the moderation effects are insignificantly related to net FDI inflows. The implication is that, when proxied by private credit, ICT development does not have a conditional impact on FDI through domestic financial sector.

Consistent with the earlier findings, the estimated coefficients of human capital are negative and largely significant except in regressions using internet usage and mobile cellular as indicators of ICT. Real GDP per capita, population and openness maintain their earlier impact. Similarly, while inflation negatively influences FDI, none of the coefficients is statistically significant.

\section{A. Sensitivity analysis}

In this section, we conduct a sensitivity analysis by repeating the regressions using domestic credit as an indicator of financial development. Findings are presented in Table 4 below.

Consistent with our earlier findings, all of the coefficients of the lagged FDI shown in Table 4 are positive and statistically significant at $1 \%$, implying a divergence away from steady state. With respect to the ICT effect, all of the proxies are positive and statistically significant at conventional levels, and these findings are in synch with the earlier evidence. Thus, a welldeveloped ICT environment spurs foreign capital inflows with a large impact stemming from fixed telephone subscriptions, with a coefficient of 0.4757 . Interestingly, by using domestic credit to proxy financial development, we observe a negative and statistically significant effect of finance on FDI suggesting that a well-developed financial sector development does not promote net inflows of FDI. Specifically, for a unit-percentage increase in domestic credit to GDP, FDI declines between 0.0465 and 0.0468 . Although the difference in the level of the effect of finance is negligible given the different indicators of ICT, our evidence implies that greater financial development in Africa results in reduced foreign capital inflows. Although 
Table 4. ICT, Finance and FDI nexus

\begin{tabular}{|c|c|c|c|c|c|}
\hline MODEL \# & 1 & 2 & 3 & 4 & 5 \\
\hline Lagged FDI & $\begin{array}{c}0.15870 * * * \\
{[0.000]}\end{array}$ & $\begin{array}{c}0.15400 * * * \\
{[0.000]}\end{array}$ & $\begin{array}{c}0.15430 * * * \\
{[0.000]}\end{array}$ & $\begin{array}{c}0.15440 * * * \\
{[0.000]}\end{array}$ & $\begin{array}{c}0.15710^{* * *} \\
{[0.000]}\end{array}$ \\
\hline ICT imports & $\begin{array}{c}0.03250 * * \\
{[0.048]}\end{array}$ & & & & \\
\hline Internet usage & & $\begin{array}{c}0.05470^{* * * *} \\
{[0.000]}\end{array}$ & & & \\
\hline Mobile cellular & & & $\begin{array}{c}0.01540 * * * \\
{[0.000]}\end{array}$ & & \\
\hline Fixed telephone & & & & $\begin{array}{c}0.47570 * * * \\
{[0.000]}\end{array}$ & \\
\hline Secured internet & & & & & $\begin{array}{c}0.03580 * * * \\
{[0.000]}\end{array}$ \\
\hline Domestic credit & $\begin{array}{c}-0.04680^{* * *} \\
{[0.000]}\end{array}$ & $\begin{array}{c}-0.04660^{* * *} \\
{[0.000]}\end{array}$ & $\begin{array}{c}-0.04660^{* * *} \\
{[0.000]}\end{array}$ & $\begin{array}{c}-0.04650^{* * * *} \\
{[0.000]}\end{array}$ & $\begin{array}{c}-0.04670^{* * *} \\
{[0.000]}\end{array}$ \\
\hline Human capital & $\begin{array}{c}-0.00430 * * * \\
{[0.000]}\end{array}$ & $\begin{array}{c}-0.00050 \\
{[0.176]}\end{array}$ & $\begin{array}{c}-0.0014 * * * \\
{[0.002]}\end{array}$ & $\begin{array}{c}-0.0057 * * * \\
{[0.000]}\end{array}$ & $\begin{array}{c}-0.0023 * * * \\
{[0.000]}\end{array}$ \\
\hline Real GDP per capita & $\begin{array}{c}-0.00110^{* * *} \\
{[0.000]}\end{array}$ & $\begin{array}{c}-0.00120^{* * *} \\
{[0.000]}\end{array}$ & $\begin{array}{c}-0.00130 * * * \\
{[0.000]}\end{array}$ & $\begin{array}{c}-0.00120 * * * \\
{[0.000]}\end{array}$ & $\begin{array}{c}-0.00120 * * * \\
{[0.000]}\end{array}$ \\
\hline Population & $\begin{array}{c}0.45330 * * * \\
{[0.000]}\end{array}$ & $\begin{array}{c}0.30570 * * \\
{[0.031]}\end{array}$ & $\begin{array}{c}0.21490^{*} \\
{[0.067]}\end{array}$ & $\begin{array}{c}0.18040 * * * \\
{[0.004]}\end{array}$ & $\begin{array}{c}0.42750 * * * \\
{[0.000]}\end{array}$ \\
\hline Trade openness & $\begin{array}{c}0.06750 * * * \\
{[0.000]}\end{array}$ & $\begin{array}{c}0.06730 * * * \\
{[0.000]}\end{array}$ & $\begin{array}{c}0.06690 * * * \\
{[0.000]}\end{array}$ & $\begin{array}{c}0.06620 * * * \\
{[0.000]}\end{array}$ & $\begin{array}{c}0.06780^{* * *} \\
{[0.000]}\end{array}$ \\
\hline Inflation & $\begin{array}{c}-0.0001 * * * \\
{[0.009]}\end{array}$ & $\begin{array}{c}-0.00004 \\
{[0.692]}\end{array}$ & $\begin{array}{c}-0.00005 \\
{[0.360]}\end{array}$ & $\begin{array}{c}-0.00010 \\
{[0.109]}\end{array}$ & $\begin{array}{c}-0.00006 \\
{[0.428]}\end{array}$ \\
\hline Constant & $\begin{array}{c}-22.64780 \\
{[0.000]}\end{array}$ & $\begin{array}{c}-15.08710 \\
{[0.047]}\end{array}$ & $\begin{array}{c}-9.90920 \\
{[0.116]}\end{array}$ & $\begin{array}{c}-8.69950 \\
{[0.011]}\end{array}$ & $\begin{array}{c}-21.32800 \\
{[0.000]}\end{array}$ \\
\hline \multicolumn{6}{|l|}{ Diagnostics } \\
\hline Time effects & YES & YES & YES & YES & YES \\
\hline Wald $\chi^{2}$ & $216,273.41$ & $541,877.61$ & $438,852.24$ & $343,104.62$ & $406,159.53$ \\
\hline Prob $>\chi^{2}$ & 0.0000 & 0.0000 & 0.0000 & 0.0000 & 0.0000 \\
\hline $\operatorname{AR}(2)[p$-value $]$ & $-1.721[0.144]$ & $-1.312[0.167]$ & $-1.361[0.183]$ & $-1.271[0.190]$ & $-1.451[0.412]$ \\
\hline Sargan test $[p-$ value $]$ & $11.321[0.252]$ & $15.211[0.200]$ & $14.903[0.311]$ & $17.171[0.312]$ & $18.031[0.318]$ \\
\hline Number of groups & 46 & 46 & 46 & 46 & 46 \\
\hline
\end{tabular}

(Notes) $* * *$ and $* * *$ denote significance at 10,5 , and $1 \%$ respectively. Windmeijer (2005) robust standard errors are used.

consistent with Anyanwu (2011), and Walsh and Yu (2010), this result contrasts sharply with our earlier finding on the positive link between financial development and FDI.

Indeed, to the extent that domestic credit provided by the financial sector (comprising monetary authorities, deposit money banks, and other contractual savings institutions) includes all credits and financial resources to various sectors on a gross basis, higher domestic credit may increase domestic capital, hence encouraging greater substitution of foreign capital. A key implication 
of the negative results shows that greater levels of domestic credit do not encourage foreign capital inflows. Antras et al. (2009) advance the possibility that greater financial development in host countries can have a negative direct effect on FDI, especially if it encourages greater substitution of foreign outsourcing for integration. The motive is that lenders are less inclined to require the multinational firms to hold a share in its financially vulnerable sectors because strong financial institutions ensure that the efforts of entrepreneurs are monitored and align with value for money. Thus, greater domestic financial development may therefore lessen external pressure on multinational firms to hold a controlling interest in partner foreign firms involved in its supply value chain, thereby reducing its engagement in cross-border capital flows. There is ample evidence that, if the business environment of a host country is not committed to pursuing market-oriented economic policies for the domestic financial sector in ways that permit foreign investors to import intermediate capital goods for investment activities, the financial system may not support FDI inflows (Alfaro et al. 2004, 2006, Boateng et al. 2017).

Apart from financial development, all of the coefficients for the other variables maintain their signs and significance. Specifically, population and level of trade openness strongly promote foreign capital inflows while human capital accumulation and real GDP per capita significantly inhibit FDI inflows. Although the coefficient of inflation is also negative in all of the estimations, the effect is largely insignificant. Given the negative effect of finance on FDI, we examine whether a well-developed ICT environment dampens the deleterious impact of finance. In Table 5, we present evidence on the moderation effect of ICT relying on the multiplicative interactive term of finance and ICT.

Apart from internet usage and mobile cellular, the unconditional impact of all the ICT indicators is positive and significant. Domestic credit is robustly negative, highlighting a dampening effect of finance on FDI inflows.

Except for domestic credit and secure internet servers, the coefficients for the interaction terms are robustly positive and significant at the $1 \%$ in all columns. The implication is that, while domestic credit inhibits FDI inflows, a well-developed ICT environment dampens the deleterious effect of finance on foreign capital flows. However, this dampening effect is possible only after a certain minimum level of ICT is attained. For instance, with the coefficient of the interactive term of ICT imports and finance of 0.0039 and the coefficient of domestic credit of -0.0469 , the estimated threshold of ICT imports is $12.03 \%$ computed as [ $-(-0.0469 / 0.0039)]$. Similarly, the percentage of individuals using the internet threshold is $47 \%$, computed as [-(0.047/0.001)]. The remaining thresholds for fixed telephone and mobile cellular subscriptions per 100 people are given as 8.38 and 157.33 , respectively. Thus, for domestic credit to spur FDI, the ICT indicators should at least be greater than their respective thresholds. However, juxtaposing these threshold values with the average values of the ICT proxies suggest that the ICT environment in Africa is relatively underdeveloped since the mean values are well below 
Table 5. ICT, Finance, FDI and mediation effects

\begin{tabular}{|c|c|c|c|c|c|}
\hline & 1 & 2 & 3 & 4 & 5 \\
\hline Lagged FDI & $\begin{array}{c}0.15830 * * * \\
{[0.000]}\end{array}$ & $\begin{array}{c}0.15300^{* * *} \\
{[0.000]}\end{array}$ & $\begin{array}{c}0.15140^{* * *} \\
{[0.000]}\end{array}$ & $\begin{array}{c}0.15030^{* * *} \\
{[0.000]}\end{array}$ & $\begin{array}{c}0.15770 * * * \\
{[0.000]}\end{array}$ \\
\hline ICT imports & $\begin{array}{c}0.12730^{* * *} \\
{[0.000]}\end{array}$ & & & & \\
\hline Internet usage & & $\begin{array}{l}0.00100 \\
{[0.993]}\end{array}$ & & & \\
\hline Mobile cellular & & & $\begin{array}{c}-0.00200 \\
{[0.449]}\end{array}$ & & \\
\hline Fixed telephone & & & & $\begin{array}{c}0.23380^{* *} \\
{[0.019]}\end{array}$ & \\
\hline Secured internet & & & & & $\begin{array}{c}0.04530 * \\
{[0.069]}\end{array}$ \\
\hline Domestic credit & $\begin{array}{c}-0.04690 * * * \\
{[0.000]}\end{array}$ & $\begin{array}{c}-0.04700^{* * *} \\
{[0.000]}\end{array}$ & $\begin{array}{c}-0.04720^{* * *} \\
{[0.000]}\end{array}$ & $\begin{array}{c}-0.04860 * * * \\
{[0.000]}\end{array}$ & $\begin{array}{c}-0.04690 * * * \\
{[0.000]}\end{array}$ \\
\hline Human capital & $\begin{array}{c}-0.00450 * * * \\
{[0.000]}\end{array}$ & $\begin{array}{c}-0.00130^{* * *} \\
{[0.000]}\end{array}$ & $\begin{array}{c}-0.00110^{* * *} \\
{[0.001]}\end{array}$ & $\begin{array}{c}-0.00530 * * * \\
{[0.000]}\end{array}$ & $\begin{array}{c}-0.00250 * * * \\
{[0.000]}\end{array}$ \\
\hline Real GDP per capita & $\begin{array}{c}-0.00120 * * * \\
{[0.000]}\end{array}$ & $\begin{array}{c}-0.00110^{* * *} \\
{[0.000]}\end{array}$ & $\begin{array}{c}-0.00120 * * * \\
{[0.000]}\end{array}$ & $\begin{array}{c}-0.00110^{* * *} \\
{[0.000]}\end{array}$ & $\begin{array}{c}-0.00120 * * * \\
{[0.000]}\end{array}$ \\
\hline Population & $\begin{array}{c}0.45050^{* * *} \\
{[0.000]}\end{array}$ & $\begin{array}{l}0.20680 \\
{[0.119]}\end{array}$ & $\begin{array}{c}0.34060^{* *} \\
{[0.011]}\end{array}$ & $\begin{array}{l}0.08510 \\
{[0.284]}\end{array}$ & $\begin{array}{c}0.43310^{* * *} \\
{[0.000]}\end{array}$ \\
\hline Trade openness & $\begin{array}{c}0.06760 * * * \\
{[0.000]}\end{array}$ & $\begin{array}{c}0.06580 * * * \\
{[0.000]}\end{array}$ & $\begin{array}{c}0.06690 * * * \\
{[0.000]}\end{array}$ & $\begin{array}{c}0.06720 * * * \\
{[0.000]}\end{array}$ & $\begin{array}{c}0.06780 * * * \\
{[0.000]}\end{array}$ \\
\hline Inflation & $\begin{array}{c}-0.00005 \\
{[0.513]}\end{array}$ & $\begin{array}{c}-0.00004 \\
{[0.367]}\end{array}$ & $\begin{array}{c}-0.00006^{*} \\
{[0.098]}\end{array}$ & $\begin{array}{c}-0.00009 * * \\
{[0.043]}\end{array}$ & $\begin{array}{c}-0.00012 * * \\
{[0.010]}\end{array}$ \\
\hline \multicolumn{6}{|l|}{ Interactions: } \\
\hline Domestic credit $\times$ ICT imports & $\begin{array}{c}0.0039 * * * \\
{[0.000]}\end{array}$ & & & & \\
\hline Domestic credit $\times$ Internet usage & & $\begin{array}{c}0.00100 * * * \\
{[0.001]}\end{array}$ & & & \\
\hline $\begin{array}{l}\text { Domestic credit } \times \text { Mobile } \\
\quad \text { cellular }\end{array}$ & & & $\begin{array}{l}0.00030 * * * \\
{[0.000]}\end{array}$ & & \\
\hline $\begin{array}{l}\text { Domestic credit } \times \text { Fixed } \\
\text { telephone }\end{array}$ & & & & $\begin{array}{c}0.00580 * * * \\
{[0.000]}\end{array}$ & \\
\hline $\begin{array}{l}\text { Domestic credit } \times \text { Secured } \\
\quad \text { internet }\end{array}$ & & & & & $\begin{array}{c}-0.00010 \\
{[0.620]}\end{array}$ \\
\hline Constant & $\begin{array}{c}-22.4226 \\
{[0.000]}\end{array}$ & $\begin{array}{l}9.6601 \\
{[0.171]}\end{array}$ & $\begin{array}{c}-16.7468 \\
{[0.020]}\end{array}$ & $\begin{array}{c}-3.8947 \\
{[0.363]}\end{array}$ & $\begin{array}{c}-21.6128 \\
{[0.000]}\end{array}$ \\
\hline \multicolumn{6}{|l|}{ Diagnostics } \\
\hline Time effects & YES & YES & YES & YES & YES \\
\hline Wald $\chi^{2}$ & $2.56 \mathrm{e}+06$ & $704,484.56$ & $614,498.89$ & $1.62 \mathrm{e}+06$ & $764,789.08$ \\
\hline Prob $>\chi^{2}$ & 0.0000 & 0.0000 & 0.0000 & 0.0000 & 0.0000 \\
\hline AR (2) $[p$-value $]$ & $-1.045[0.135]$ & $-1.403[0.142]$ & $-1.204[0.191]$ & $-1.411[0.111]$ & $-1.306[0.131]$ \\
\hline Sargan test $[p$-value $]$ & $12.481[0.241]$ & $11.211[0.321]$ & $14.201[0.290]$ & $14.391[0.364]$ & $13.211[0.305]$ \\
\hline Number of groups & 46 & 46 & 46 & 46 & 46 \\
\hline
\end{tabular}

(Notes) $*, * *$ and $* * *$ denote significance at 10,5 and $1 \%$ respectively. Windmeijer (2005) robust standard errors are used. 
their respective optimal levels, an indication that there is still room for improvement. Beyond these thresholds, ICT infrastructure becomes more developed to exert a positive influence on the financial markets by aiding in efficient resource allocation, better financial intermediation, improved risk management practices, and informational efficiency, all of which are essential in FDI inflows. Indeed, a sound ICT environment decreases physical bottlenecks such as distance costs and time constraints. Thus, better ICT development decreases financial intermediation costs and contributes to the proliferation of branchless banking services, thereby enhancing financial access and inclusion.

The impacts of the other control variables continue to confirm what was previously observed, except in this case inflation is largely significant. For all the models estimated, the high values of the Wald $\chi^{2}$ show that the overall models are jointly significant. The Sargan tests support the null hypothesis of valid over-identifying restrictions while the $p$-values of the test for second -order autocorrelation $[\mathrm{AR}(2)]$ favors the null hypothesis of no second-order autocorrelation. These lend credence to the validity of our findings.

\section{Summary and Policy Implications}

Efforts aimed at encouraging FDI in Africa have not yielded the desired results. Empirically, apart from the macroeconomic and political factors, studies on the drivers of FDI have not been rigorous in examining whether recent advances in the continent's ICT infrastructure and domestic financial development have any role in attracting foreign capital. In this study, we re-examine the determinants of FDI inflows, paying special attention to the ICT and financial sector environments. Using a panel dataset of 46 countries in Africa over the period 1980 2016, evidence from our study shows that well-developed ICT infrastructure robustly spurs FDI regardless of the measure of ICT. On the other hand, the impact of domestic financial sector development on FDI is conditioned on the proxy of finance. Specifically, while the ratio of domestic credit to GDP does not appear to promote foreign capital inflows, higher levels of ICT in the environment dampen the deleterious effect of finance on FDI. We document the threshold levels of ICT before it can exert such a dampening effect.

At the policy level, despite the abysmal performance of FDI in Africa there is still much room for optimism, as given the evidence from our study, recent development in the region's ICT environment and financial sector development may help attract inflows. Thus, it is imperative for policymakers to encourage the diffusion of ICT while creating synergies within a country's domestic financial markets. In this regard, government intervention is essential to improve on a country's technological infrastructure while the Central bank maintains sound supervision of the financial sectors. Furthermore, implementing prudent macroeconomic policies 
in more open economies is also crucial in attracting needed levels of FDI in Africa. This study can be extended and applied to other developing countries in Africa with similar trends regarding ICT, financial development and FDI, among others. Future studies can thoroughly investigate possible threshold effects of ICT on FDI using financial development as the threshold variable. Here, a sample splitting approach can be fit where the precise impact of ICT on FDI inflows is based on whether countries operate below or above some estimated threshold value of financial development.

\section{References}

Addison, T., and A. Heshmati. (2003). The new global determinants of FDI flows to developing countries the importance of ICT and democratization, World Institute for Development Economics Research (WIDER) Discussion Paper No. 2003/45.

Aker, J. C., and I. M. Mbiti. (2010). "Mobile phones and economic development in Africa." The Journal of Economic Perspectives 24, no. 3, 207-232.

Albiman, M. M., and Z. Sulong. (2016). "The role of ICT use to the economic growth in sub Saharan African region (SSA)." Journal of Science and Technology Policy Management 7, no. 3, 306-329.

Albiman, M. M., and Z. Sulong. (2017). "The linear and non-linear impacts of ICT on economic growth, of disaggregate income groups within SSA region.” Telecommunications Policy 41, no. 7-8, 555-572.

Alfaro, L., A. Chanda, S. Kalemli-Ozcan, and S. Sayek. (2006). How does foreign direct investment promote economic growth? Exploring the effects of financial markets on linkages, National Bureau of Economic Research Working Paper No. w12522.

Alfaro, L., A. Chanda, S. Kalemli-Ozcan, and S. Sayek. (2009). "FDI, productivity and financial development." The World Economy 32, no. 1, 111-135.

Alsan, M., D. E. Bloom, and D. Canning. (2006). "The effect of population health on foreign direct investment inflows to low- and middle-income countries." World Development 34, no. 4, 613-630.

Andinuur, J. (2013). "Inflation, foreign direct investment and economic growth in Ghana." MPhil thesis, University of Ghan.

Antras, P., M. A. Desai, and C. F. Foley. (2009). "Multinational firms, FDI flows, and imperfect capital markets." Quarterly Journal of Economics 124, no. 3, 1171-1219.

Anyanwu, J. C. (2011). Determinants of foreign direct investment inflows to Africa, 1980-2007. Working Paper Series Number 136, African Development Bank, Tunis, Tunisia.

Arellano, M., and S. Bond. (1991). "Some tests of specification for panel data: Monte Carlo evidence and an application to employment equations." The Review of Economic Studies 58, no. 2, 277-297.

Aseidu, E. (2002). "On the determinants of foreign direct investment to developing countries: Is Africa different?." World Development 30, no. 1, 107-119.

Asongu, S. (2015). "The impact of mobile phone penetration on African inequality." International Journal of Social Economics 42, no. 8, 706-716. 
Baltagi, B. H., P. O. Demetriades, and S. H. Law. (2009). "Financial development and openness: Evidence from panel data." Journal of Development Economics 89, 285-296.

Blundell, R., and S. Bond. (1998). "Initial conditions and moment restrictions in dynamic panel data models." Journal of Econometrics 87, no. 1, 115-143.

Boateng, E., M. Amponsah, and C. A. Baah. (2017). "Complementarity effect of financial development and FDI on investment in sub-Saharan Africa: a panel data analysis." African Development Review 29, no. 2, 305-318.

Cardona, M., T. Kretschmer, and T. (2013). "Strobel. ICT and productivity: conclusions from the empirical literature." Information Economics and Policy 25, no. 3, 109-125.

Choi, C. (2003). "Does the internet stimulate inward foreign direct investment?." Journal of Policy Modeling 25, no. 4, 319-326.

Dewan, S., and K. L. Kraemer. (2000). "Information technology and productivity: Evidence from country-level data." Management Science 46, no. 4, 548-562.

Easterlin, R. A. (1981). "Why isn't the whole world developed?." Journal of Economic History 41, no. $1,1-19$.

Eicher, T. S. and P. Kalaitzidakis. (1997). The human capital dimension to foreign direct investment: training, adverse selection and firm location. University of Washington, Department of Economics Working Papers 97-03.

Fakher, A. (2016). "The impact of investment in ICT sector on foreign direct investment: Applied study on Egypt." Review of Integrative Business and Economics 5, no. 2, 151-166.

Gani, A. and B. Sharma. (2003). "The effects of information technology achievement and diffusion on foreign direct investment." Perspectives on Global Development and Technology 2, no. 2, 161-178.

Hausmann, R., and E. Fernandez-Arias. (2000). The new wave of capital inflows: Sea change or just another title: Inter-American Development Bank working paper number 417.

Hull, L., and I. Tesar. (2003). Risk, specialization and the composition of international capital flows. University of Michigan, Working Paper.

Ibrahim, M. (2018). "Interactive effects of human capital in finance-economic growth nexus in sub-Saharan Africa." Journal of Economic Studies 45, no. 6, 1192-1210.

Ibrahim, M., and P. Alagidede. (2017). "Financial Development, Growth Volatility and Information Asymmetry in sub-Saharan Africa: Does Law Matter?." South African Journal of Economics 85, no. $4,570-588$.

Ibrahim, M., and P. Alagidede. (2018a). "Effect of financial development on economic growth in subSaharan Africa." Journal of Policy Modeling 40, no. 6, 1104-1125.

Ibrahim, M., and P. Alagidede. (2018b). "Nonlinearities in financial development and economic growth nexus: Evidence from sub-Saharan Africa." Research in International Business and Finance 46, 95-104.

Ibrahim, M., and Y. A. Sare. (2018). "Determinants of financial development in Africa: How robust is the interactive effect of trade openness and human capital?." Economic Analysis and Policy 60, 18-26.

Jaspersen, F. Z., A. H. Aylward, and A. D. Knox. (2000). "The effects of risk on private investment: Africa compared with other developing areas." In Investment and risk in Africa, edited by P. Collier, 
and C. Pattilo, 71-95. New York: St. Martin's Press.

Kida, N. M. (2014). "Foreign direct investment environment and economic growth." Acta Universitatis Danubius, Economica 10, no. 4, 31-41.

Ko, K. W. (2007). "Internet externalities and location of foreign direct investment: A comparison between developed and developing countries." Information Economics and Policy 19, no. 1, 1-23.

Langmia, K. (2005). "The role of ICT in the economic development of Africa: The case of South Africa." International Journal of Education and Development using Information and Communication Technology 2, no. 4, 144-156.

Latif, Z., Y. Mengke, Danish, S. Latif, L. Ximei, Z. H. Pathan, S. Salam, and Z. Jianqiu. (2018). "The dynamics of ICT, foreign direct investment, globalization and economic growth: Panel estimation robust to heterogeneity and cross-sectional dependence." Telematics and Informatics 35, 318-328.

Latif, Z., W. Xin, D. Khan, K. Iqbal, Z. H. Pathan, S. Salam, and N. Jan. (2017). "ICT and sustainable development in South Asian countries." Human Systems Management 36, no. 4, 353-362.

Lucas, R. (1990). "Why doesn't capital flow from rich to poor countries?" American Economic Review 80, 92-96.

Lydon, R., and M. Williams. (2005). "Communications networks and foreign direct investment in developing countries." Communications and Strategies 58, no. 2, 43-60.

McKinnon, R. I. (1973). Money and capital in economic development. Brookings Institution, Washington, DC.

Mina, W. (2007). "The location determinants of FDI in the GCC countries." Journal of Multinational Financial Management 17, no. 4, 336-348.

Munemo, J. (2017). "Foreign direct investment and business start-up in developing countries: The role of financial market development." The Quarterly Review of Economics and Finance 65, 97-106.

Niebel, T. (2018). "ICT and economic growth - Comparing developing, emerging and developed countries." World Development 104, 197-211.

Pohjola, M. (2002). "The new economy in growth and development." Oxford Review of Economic Policy 18, no. 3, 380-396.

Reynolds, T., C. Kenny, J. Liu, and C. Z-W. Qiang. (2004). "Networking for foreign direct investment: The telecommunications industry and its effect on investment." Information Economics and Policy $16,159-164$.

Roodman, D. (2009). "A note on the theme of too many instruments." Oxford Bulletin of Economics and Statistics 71, no. 1, 135-158.

Sarbu, M-R., and L. Carp. (2015). "The impact of foreign direct investment on economic growth: The case of Romania." Acta Universitatis Danubius, Economica 11, no. 4, 127-137.

Shaw, E. S. (1973). Financial deepening in economic development, Oxford University Press, New York.

Walsh, J. P., and J. Yu. (2010). Determinants of foreign direct investment: A sectoral and institutional approach. IMF Working Paper, WP/10/187, Asia Pacific Department.

Windmeijer, F. (2005). "A finite sample correction for the variance of linear efficient two-step GMM estimators." Journal of Econometrics 126, no. 1, 25-51.

World Investment Report. (2017). Investment and the digital economy, United Nations Conference on 
Trade and Development (UNCTAD), Geneva: Switzerland.

Yousefi, A. (2011). "The impact of information and communication technology on economic growth: Evidence from developed and developing countries." Economics of Innovation and New Technology 20, no. 6, 581-596. 